\title{
Evaluation and identification of resistance to powdery mildew in Indian wheat varieties under artificially created epiphytotic
}

\author{
Vikas Gupta*, R. Selvakumar, Satish Kumar, C. N. Mishra, V. Tiwari and Indu Sharma \\ ICAR-Indian Institute of Wheat and Barley Research, Karnal-132001 (Haryana), INDIA \\ *Corresponding author. E-mail: vikasdwr@gmail.com \\ Received: September 10, 2015; Revised received: February 2, 2016; Accepted: April 6, 2016
}

\begin{abstract}
Wheat production is globally weighed down by several biotic factors of which rusts and powdery mildew are the most important. Powdery mildew, caused by Blumeria graminis f. sp. tritici, is becoming a disease of major importance in the North Western Plains Zone and Northern Hills Zone of the country. In the present context of climate variability, diseases like powdery mildew can assume greater importance in wheat breeding programs. Importance of basic studies on powdery mildew is the need of hour. A set of 370 Indian bread wheat, durum, dicoccum and triticale varieties were screened using mixture of natural occurring pathotypes from four locations (viz., Karnal, Ludhiana, Dhaulakuan and Yamunanagar) under polyhouse conditions. Data were recorded on the severity of infection based on 0-9 scale. Out of 370, only 23 varieties (Amrut, DDK 1025, DWR 1006, DWR 195, GW 1139, HD 4672, HD 4530, HD 2278, HD 1981, DDK 1001, HI 8627, Jay, TL 2942, DT 46, K 8020, DDK 1029, K 9107, K 816, Lok 1, MACS 6145, DDK 1009, NP 111 and NP 200) had shown immune reaction (0) whereas 150, 83 and 114 varieties have shown resistance (1-3), moderately susceptible (4-6) and highly susceptible (>6) response respectively against powdery mildew. Data indicated that there is an urgent need to broaden the genetic base of wheat by identifying and introgressing new sources of powdery mildew resistance. With limited sources of PM resistance available, above identified genotypes can be further used and characterized for resistance breeding programs in India.
\end{abstract}

Keywords: Blumeria graminis f. sp. tritici, Epiphytotic, Pathotypes, Powdery mildew, Released varieties

\section{INTRODUCTION}

Wheat (Triticum aestivum L.) is one of the cereals grown worldwide and a major source of energy, protein and fibre in human diet. It is the second most important crop after rice in India and is grown on $30 \mathrm{~m}$ ha area. In India, the annual wheat production was 93.90 million tonnes whereas global wheat production was estimated at 704.08 million tonnes during 2011-12 (Anonymous, 2012). Three species of wheat are cultivated in India viz., T. aestivum (Bread wheat), T. $d u$ rum (Macaroni wheat) and the T. dicoccum (Emmer wheat) occupying around $95 \%, 4 \%$ and $1 \%$ area. Wheat production and productivity need to be enhanced to meet the growing demand of ever increasing population. Wheat crop production is affected by several biotic (rusts, Karnal bunt, powdery mildew and loose smut) and abiotic factors (heat, drought, salinity and waterlogging) (Chatrath et al., 2007).

North Western Plains Zones has been considered as the pivotal zone for the historical green revolution and at present it is the major contributor to the total wheat production in the country. Higher yield potential coupled with disease resistance in the wheat varieties is considered essential for sustaining wheat production in this zone. Stripe rust and powdery mildew are the ma- jor diseases of Northern Hills Zone and North Western Plains Zones of India. Heavy economic losses around the globe have reported due to stripe rust (caused by Puccinia striiformis) and powdery mildew [caused by Blumeria graminis f. sp. tritici (Bgt)] diseases of wheat (Alam et al., 2013; Chen, 2005). Bgt is a biotrophic fungus distributed throughout world especially in cool or warm and humid climatic areas (Priestley and Bayles, 1998; Huang et al., 2004).

The finding of Biffen (1905) led to the foundation of systematic resistance breeding to diseases followed by discovery of gene for gene hypothesis by Flor (1956). These discoveries led to the identification and deployment of resistance genes and understanding the resistance mechanism. Till date, more than 60 resistance genes have been identified and designated on 50 loci (Pm1- Pm50). Out of these, Pm1, Pm 3, Pm 4, Pm 5, $\mathrm{Pm} 8 / \mathrm{Pm} 17$ and $\mathrm{Pm} 24$ are having multiple alleles (Mwale et al., 2014). Thirty three designated genes have been identified from $T$. aestivum and remaining genes have been identified from related species and genera.

In India, Powdery mildew disease of wheat has assumed importance especially in North Western Plains zone, Northern Hills zone and Southern Hills zone (Singh et al., 2009). Indian germplasm lacks variability 
for powdery mildew resistance as evident from the susceptibility of wheat varieties developed recently in India (Singh et al., 2009 ). Nine out of 400 germplasm lines evaluated at multiple locations for four years were found resistant indicating resistance breeding for powdery mildew is not a breeding objective in Indian breeding programmes. However, sporadic incidence of powdery mildew has been reported from Rajasthan, Maharashtra and Karnataka (Arya and Ghemawat, 1953; Gadore and Patwardhan, 1965; Patil et al., 1969). Not much work on powdery mildew resistance in wheat was carried out in the past. Recently, two powdery mildew resistance genes, identified in $T$. boeoticum $\left(\mathrm{A}^{\mathrm{b}} \mathrm{A}^{\mathrm{b}}\right)$ accession pau5088 (PmTb7A.1 and PmTb7A.2) and transferred to $T$. aestivum using marker assisted selection (Elkot et al., 2015; Chhuneja et al., 2015). It is also by and large accepted that in the absence of diverse genetic pool, the breeding approach may not prove successful. The genetic diversity for resistance to powdery mildew within wheat needs to be enriched with identification and mobilization of new genes. Therefore, the present study was taken to identify the powdery mildew resistance of released varieties for direct use in breeding programmes.

\section{MATERIALS AND METHODS}

The experiment was carried out during rabi season (2013-14) at ICAR- Indian Institute of Wheat and Barley Research (ICAR-IIWBR), Karnal in polyhouse under controlled conditions (Latitude $29.43^{\circ} \mathrm{N}$, longitude $76.58^{\circ} \mathrm{E}$ and altitude $245 \mathrm{~m}$ ) on sandy clay loam soil. The plant material consisted of 370 released wheat varieties of which $326 \mathrm{~T}$. aestivum, $36 \mathrm{~T}$. durum, $5 \mathrm{~T}$. dicoccum and 3 Triticale (X Triticosecale Wittmack) varieties. The varieties were timely sown as hills ( 5 seeds/ hill) with a spacing of $20 \mathrm{~cm}$ following all the recommended package of practices for raising a good wheat crop in the polyhouse. Bgt infected plants were collected from four locations viz., Ludhiana, Karnal, Yamunanagar and Dhaulakuan during the early crop season. The inoculum was multiplied on susceptible variety PBW 343 grown in plastic pots. The mixed inoculum obtained from all locations was dusted on the test genotypes and the infected pots were also placed in the polyhouse to create epiphytotic condition. After every 7-8 days, the old batch of infected plant pots was replaced with fresh infected plants in pots. The temperature $\left(22-25^{\circ} \mathrm{C}\right)$ and humidity $(80-90 \%)$ was maintained during the period of study. The wheat seedlings were inoculated at 25-30 days after planting which was the most vulnerable period of susceptibility. Data was recorded when the infection on susceptible check PBW 343 was at its maximum following the scale 0-9 given by Leath and Heun (1990). The scale is based on infection types where $0=$ immune (no visible sign of infection); $1-3=$ resistant $(1=$ flecks with no necrosis, $2=$ necrosis and $3=$ chlorosis, while amount of mycelium went from none to detectable amount); 4-6 = moderately susceptible (chlorotic area decreasing in amount but mycelium an $\mathrm{d}$ conidia production increases); 7-9 = Highly susceptible (increasing amount, size and density of mycelium and conidia to a compatible reaction)

\section{RESULTS AND DISCUSSION}

Released varieties of wheat (T. aestivum, T. durum, $T$. dicoccum and triticale) were screened for powdery mildew resistance under artificially created epiphytotic conditions (mixed population of Bgt). Released varieties exhibited powdery mildew reaction ranging from immune score of 0 to highly susceptible of 9 according to the scale given by Leath and Heun (1990). Of the 370 varieties, only 23 varieties (Amrut, DDK 1025, DWR 1006, DWR 195, GW 1139, HD 4672, HD 4530, HD 2278, HD 1981, DDK 1001, HI 8627, Jay, TL 2942, DT 46, K 8020, DDK 1029, K 9107, K 816, Lok 1, MACS 6145, DDK 1009, NP 111 and NP 200) showed immune reaction whereas 150,84 and 113 varieties showed resistant, moderately susceptible and highly susceptible reaction respectively. The varieties differed in their reaction and have been classified into different classes based on number of pustules on flag leaf (Table 1).

Out of $326 T$. aestivum varieties, only 12 varieties (DWR 1006, DWR 195, HD 2278, HD 1981, HI 8627, K 8020, K 9107, K 816, LOK 1, MACS 6145, NP 111, NP 200) have shown immune reaction where as 135 varieties showed resistant reaction (1-3), 79 showed moderately susceptible reaction and 100 varieties showed highly susceptible reaction (Table 2). Out of

Table 1. Powdery mildew reaction status of released varieties under epiphytotic condition.

\begin{tabular}{|c|c|c|c|}
\hline S. N. & Powdery mildew Scale & No. of varieties & Powdery mildew reaction \\
\hline 1 & 0 & 23 & Immune \\
\hline 2 & 1 & 38 & \\
\hline 3 & 2 & 46 & \\
\hline 4 & 3 & 66 & Resistant \\
\hline 5 & 4 & 8 & \\
\hline 6 & 5 & 75 & \\
\hline 7 & 6 & 1 & Moderately Susceptible \\
\hline 8 & 7 & 32 & \\
\hline 9 & 8 & 2 & \\
\hline \multirow[t]{2}{*}{10} & 9 & 79 & Highly susceptible \\
\hline & Total & 370 & \\
\hline
\end{tabular}


Table 2. Powdery mildew reaction of released varieties of bread wheat (T. aestivum).

\begin{tabular}{|c|c|c|c|c|}
\hline $\begin{array}{l}\text { S. } \\
\text { N. }\end{array}$ & $\begin{array}{l}\text { Powdery } \\
\text { mildew } \\
\text { Scale }\end{array}$ & $\begin{array}{l}\text { No. of } \\
\text { varie- } \\
\text { ties }\end{array}$ & Name of Varieties & $\begin{array}{l}\text { Powdery } \\
\text { mildew re- } \\
\text { action }\end{array}$ \\
\hline 1 & 0 & 12 & $\begin{array}{l}\text { DWR 1006, DWR 195, HD 2278, HD 1981, HI 8627, K 8020, K 9107,K } \\
\text { 816,LOK 1,MACS 6145,NP 111,NP 200 } \\
\text { CPAN 1676, DBW 16, DL 788-2, DL 784-3,DL 153-2, GW 190, GW 40, } \\
\text { GW 173, HPW 251,HUW 12, HW 517, HD 2281, HD 1982, HI 385,HB }\end{array}$ & Immune \\
\hline 2 & 1 & 32 & $\begin{array}{l}\text { 208, HD 2833, HUW 318, HYB 277, HW 1095, K 9423, K 9533, K } 65 \text {, } \\
\text { Lerma Rojo, MPO 1106,NP 100,NI 747-19,Narbada-4, NARMADA 112, } \\
\text { NI } 345 \text {,VL 804,WL1562,WH 283 } \\
\text { DL 803-3, GW 18, HW 1085, HS 207, HD 2643,HD 1925, HD 2236, HD } \\
\text { 2967, HD 2189,HUW 55,HP } 1761, \text { HY 5, HY } 12, \text { K 8027, K 88/8804/ }\end{array}$ & \\
\hline 3 & 2 & 41 & $\begin{array}{l}\text { KAMAL, LAL Bahadur, MP 1142, NP 852, NP 792, NP 818, NW 2036, } \\
\text { NI 5439, NIAW 301, PBW 226, PBN 51, PV 18, Raj 4037, RAJ 2184, } \\
\text { Sonaora 64,Sagarika, UP 215, UP 368, UP 1109, UP 2382,VL 829,VL } \\
\text { 401,VL 616,WL 2265,WH 291,WG 377,WH 542 }\end{array}$ & Resistant \\
\hline & & & $\begin{array}{l}\text { A - 8, CPAN 3004, C 591, C 285, DWR 162, DBW 17, DBW 39, GW 89, } \\
\text { GW 322, GW 273, HI 1077,HP 1102, HPW 42, HUW 37, HUW 510, HS } \\
\text { 365,HYB 65, HI 784, HS 86, HS 277, HD 2851, HD 2402, HD 2204, HD } \\
2385 \text {, HD 2380, HI 977, HP 1493, HD 2307, HW 5207, TAWA 267, JW }\end{array}$ & \\
\hline 4 & 3 & 62 & $\begin{array}{l}\text { 3020,J 405, K 7410, K 7903, KRL 213, K 852, K 53, MP 1203, MACS } \\
\text { 2694, MACS 6273, NW 1076, NP 125, NP 165, NP 761, NARMADA 195, } \\
\text { NP 884, NW 1067, NIAW 34, NP 200, PBW 154, PBN 142, RAJ 3765, } \\
\text { Sonak, UP 2526, VL 719, VL 738, VL 802, WH 533, WL 410, WL 711, WH } \\
\text { 711, WH } 331\end{array}$ & \\
\hline 5 & 4 & 8 & $\begin{array}{l}\text { Cow (w)-1, HI 1418, NW 1014, NW 1012,PBW 299, PBW 54, UP 2338, VL } \\
832\end{array}$ & \\
\hline & & & $\begin{array}{l}\text { Ajanta, AKAW 1071, Arpa (CG 5011), A 90, BW 11, C 281, D 134, DPW } \\
\text { 621-50, GW 503, GW 496, GW 366, GW 10, GW 120, GABO, WG 357, } \\
\text { HPW 184, HS 240, HS 295, HYB 633, HP 1633, HDR 77, HD 2824, HD }\end{array}$ & \\
\hline 6 & 5 & 70 & $\begin{array}{l}\text { 2135, HD 1941, HP 1209, HS 1097-17, HD 2177, HYB 11, HD 2610, HW } \\
657 \text {, HS 524, Federation, JOB 666, JWS 17, K 68, K 8434, K 9465, K 9351, } \\
\text { K 9162, K 9006, K 8962, K 78, MP 4010, MACS 2496, NP 52, NP 775, } \\
\text { NIAW 917, NP 836, NP 760, NP 715, NP 721, NP 718, NP 737, PBW 373, } \\
\text { PBW 222, PBW 509, PBW 396, RAJ 4083, Raj 1972,S onalika, UP 115, UP } \\
\text { 2565, UP 2113, UAS 304, Vijay, VL 421, VINATA, VL 404, NP 839, WH } \\
1021\end{array}$ & $\begin{array}{l}\text { Moderately } \\
\text { Susceptible }\end{array}$ \\
\hline 7 & 6 & 1 & $\begin{array}{l}\text { PBW } 343 \\
\text { AKAW } 3722 \text {, C } 306 \text {, DWR 225, DBW 14, HPW 147, HI 1454, HUW } 206 \text {, }\end{array}$ & \\
\hline 8 & 7 & 28 & $\begin{array}{l}\text { HUW } 234, \text { HD } 2270 \text {, HD } 2733 \text {, HPW } 155 \text {, HI } 1500 \text {, HD 2428, HD } 2687 \text {, } \\
\text { Type } 11, \text { K } 0307, \text { KRL 210, KRL 1-4, KRL 19, KSML 3, NP 12,NI } 5643 \text {, } \\
\text { NP } 120, \text { NP 114, NP } 830, \text { PBW 443, Raj 4120, WH } 147\end{array}$ & \\
\hline 9 & 8 & 2 & $\begin{array}{l}\text { HS } 375 \text {, HD } 2932 \\
\text { Chhoti Lerma, CPAN } 1796 \text {, CBW 38, Durgapura 65, HUW 468, HUW 213, } \\
\text { HD 2327, HD 2781,HD 2285, HD 1949, HD 2009, HS 420, HS 1138-6-4, }\end{array}$ & \\
\hline 10 & 9 & 70 & $\begin{array}{l}\text { HD 2329, HW 2045, HPW 89, HI 1544, HW 741, J 24, J 1-7, Kharchia Lo- } \\
\text { cal, MLKS 11, Monphya 3-2, NP 771, NP 710, NP 846, NI 179, NP 770, NP } \\
\text { 809, NP 04, NP 824, NP 823, NP 825, NP 101, PBW 12, PBW 533, PBW } \\
\text { 120, PBW 138, PBW 175, PBW 502, PBW 65, Raj 3777, RW 3016, RW } \\
\text { 346, Raj 1482, Raj 1114, Raj 821, Rajmolyarodhak, Ridley, Ratan (CG } \\
\text { 5016), RS 31-1, Raj 4125, Sidhi 2010, Safedlarma,S KAML 1, SWL 8, Shar- } \\
\text { batiSonara, SKW 196, Utkalika,UP 2121, UP 2003, UP 301, UP 2584, UP } \\
\text { 2554,UP 2572, UP 2425, UP 262, WH 416, WH 157,WR 544 }\end{array}$ & $\begin{array}{l}\text { Highly sus- } \\
\text { ceptible }\end{array}$ \\
\hline & Total & 326 & & \\
\hline
\end{tabular}

135 resistant varieties, powdery mildew reaction of 1 was showed by 32 varieties, reaction of 2 was showed by 41 and reaction of 3 was showed by 62 varieties. Similarly in 79 moderately susceptible varieties, powdery mildew reaction of 4,5 and 6 was showed by 8 , 70 and 1 varieties respectively. Out of 100 varieties exhibiting highly susceptible reaction, powdery mildew reaction of 7, 8 and 9 was showed by 28,2 and 70 varieties, respectively. It was observed from this data $45.08 \%$ released varieties in T. aestivum group exhibited resistance (Immune and resistance) against powdery mildew pathotypes.

Thirty six $T$. durum varieties were screened for their resistance against mixture of pathotypes under artificially created epiphytoic conditions (Table 3 ). Only 5 varieties showed immune reaction (Amrut, GW 1139, 
Table 3. Powdery Mildew reaction of released varieties of Durum Wheat (T. durum).

\begin{tabular}{lllll}
\hline S. N. & $\begin{array}{l}\text { Powdery mildew } \\
\text { Scale }\end{array}$ & $\begin{array}{l}\text { No. of } \\
\text { varieties }\end{array}$ & Name of Varieties & $\begin{array}{l}\text { Powdery mildew } \\
\text { reaction }\end{array}$ \\
\hline 1 & 0 & 5 & Amrut, GW 1139,HD 4672, HD 4530,Jay & Immune \\
2 & 1 & 5 & DWR 185, HD 4502,HI 8381, NIDW 295, WH 912 & \\
3 & 2 & 4 & GW 1, MPO 1215, MACS, 2846, UAS 415 & Resistant \\
4 & 3 & 4 & Baxi 288-18, MACS 3125, MACS 1967, WH 896 & \\
5 & 4 & - & & Moderately Susceptible \\
6 & 5 & 5 & HI 7483, HI 8498,MPO 215, NP 404, PDW 274 & \\
7 & 6 & - & - & Highly susceptible \\
8 & 7 & 4 & A-9-30-1, A 206,JNK 4, W 184,Raj 911 & \\
9 & 8 & - & Bijiga yellow, JU 12, MACS 9, Motia,PDW 291, & \\
10 & 9 & 9 & PDW 233,PDW 215, Raj 1555, Raj 6560 & \\
& & 36 & & \\
\hline
\end{tabular}

Table 4. Powdery mildew reaction of released varieties of T. dicoccum and Triticale.

\begin{tabular}{|c|c|c|c|c|c|c|}
\hline \multirow{2}{*}{$\begin{array}{l}\text { S. } \\
\text { N. }\end{array}$} & \multirow{2}{*}{$\begin{array}{l}\text { Powdery mildew } \\
\text { Scale }\end{array}$} & \multicolumn{2}{|c|}{ No. of varieties } & \multicolumn{2}{|l|}{ Name of Varieties } & \multirow{2}{*}{$\begin{array}{l}\text { Powdery mildew } \\
\text { reaction }\end{array}$} \\
\hline & & Dicoccum & Triticale & Dicoccum & Triticale & \\
\hline 1 & 0 & 4 & 2 & $\begin{array}{l}\text { DDK 1001,DDK 1025, } \\
\text { DDK 1029,DDK } 1009\end{array}$ & $\begin{array}{l}\text { DT 46, } \\
\text { TL } 2942\end{array}$ & Immune \\
\hline 2 & 1 & - & 1 & & TL 2908 & Resistant \\
\hline 3 & 2 & 1 & - & MACS 2971 & & Resistant \\
\hline \multirow[t]{2}{*}{4} & $3,4,5,6,7,8$ and 9 & - & - & & & $\begin{array}{l}\text { Moderately Susceptible/ } \\
\text { Highly Susceptible }\end{array}$ \\
\hline & Total & 5 & 3 & & & \\
\hline
\end{tabular}

HD 4672, HD 4530, Jay) where as 13, 5 and 13 varieties showed resistant, moderately susceptible and highly susceptible powdery mildew reaction respectively. Out of 13 resistant reaction showing varieties, $5,4,4$ varieties exhibited reaction of 1,2 and 3 , respectively. In moderately susceptible varieties, all varieties showed reaction of 5 . However in highly susceptible category, 4 and 9 varieties exhibited reaction of 7 and 9 respectively. In $T$. durum group, $50 \%$ varieties showed resistance (immune and resistant) against powdery mildew pathotypes.

T. dicoccum (5 varieties) and Triticale (3) varieties were evaluated for powdery mildew resistance (Table 4). It was found that out of $5 T$. dicoccum varieties, 4 varieties exhibited immune reaction and one variety exhibited resistance reaction, whereas 2 and 1 varieties showed immune and resistance reaction respectively, incase of Triticale varieties. It was observed that none of the varieties were showing susceptible reaction in both $T$. dicoccum and Triticale.

In the present study, a wide range of reactions from immune to highly susceptible were shown by $T$. aestivum and $T$ durum whereas immune to resistant reactions were exhibited by $T$. dicoccum and triticale varieties. Resistance to powdery mildew was evaluated on material collected from different sources in field nurseries in Israel and Netherland (Gerechter-Amita and Vansilfhout, 1984) and they observed diverse response to powdery mildew infection ranging from highly resistant to completely susceptible. Similarly commercial wheat varieties were screened for their resistance to powdery mildew in Pakistan with a variety of reactions ranging from resistant to highly sus- ceptible (Shahzad et al., 2014). Similar results for different wheat varieties were also reported by Kaur et al. (2012) in which the susceptible check PBW 343 showed $90 \%$ leaf area infected by powdery mildew fungus. The screening period for powdery mildew was tillering stage as depicted by Rani et al. (2008) as they found late sown crop was vulnerable to powdery mildew infection as in this study powdery mildew inoculations were made after 25-30 days after sowing. They also reported susceptibility of most widely cultivar PBW 343. The varieties PBW 343, PBW 550 and DPW 621-50 have shown susceptible reactions to powdery mildew at Malan and Dhaulakuan (Gupta et $a l ., 2014)$ signifying that the recently released varieties are not having high level of resistance against this disease.

\section{Conclusion}

A wide variation for powdery mildew reaction ranging from immune (score $=0$ ) to highly susceptible (score $=7-9$ ) was observed in the present study indicating that powdery mildew resistance was not an integral part of the breeding programs of the country. Out of 370 , only 23 wheat varieties were found immune and 150 were found resistant to $B$. graminis, where as the remaining 197 varieties showed moderartely susceptible to highly susceptible powdery mildew reaction. Thus there is an urgent need to broaden the genetic base of wheat by identifying and introgressing new sources of powdery mildew resistance in the breeding lines. The T. aestivum and $T$. durum varieties identified in this study offer opportunity for their immediate use in breeding programmes for enriching resistance to powdery mil- 
dew. None of the $T$. dicoccum and Triticale varieties had shown susceptible reaction indicating higher resistance level for powdery mildew in them. Resistant varieties identified in this study may be used in breeding programme for enhancing powdery mildew resistance. These resistant varieties can be further used in identifying and characterizing resistance genes using gene matching and molecular biology tools.

\section{REFERENCES}

Anonymous. (2012). Progress report of All India Coordinated wheat and barley Improvement project 2011-12, Crop Improvement (Eds.) V Tiwari, R Chatrath, Gyanendra Singh, R Kumar, BS Tyagi, S Sareen, SK Singh, Satish Kumar, Charan Singh, CN Mishra, K Venkatesh, A Verma and Indu Sharma. Directorate of Wheat Research, Karnal, India. p 308.

Alam, M.A., Mandal, M.S.N., Wang, C. and Wanquan, J. (2013). Chromosomal location and SSR markers of a powdery mildew resistance gene in common wheat line N0308. Afr. J. Microbiol Res., 7(6):477-482.

Arya, H.C. and Ghemawat, M.S. (1953). Occurence of powdery mildew of wheat in neighbourhood of Jodhpur. Ind. Phytopathol., 15: 127-132.

Biffen, R.H.(1905). Mendal's laws of inheritance and wheat breeding. J Agri. Sci., 1: 4-48

Chatrath, R., Mishra, B., Ortiz Ferrara, G., Singh, S.K. and Joshi, A.K. (2007). Challenges to wheat production in South Asia. Euphytica, 157: 447-456.

Chen, X.M. (2005). Epidemiology and control of stripe rust (Puccinia striiformis f. sp. tritici) on wheat. Can. J. Plant Pathol., 27: 314-337.

Chhuneja, P., Yadav, B., Stirnweis, D., Hurni, S., Kaur, S., Elkot, A.F., Keller, B., Wicker, T., Sehgal, S., Gill, B.S. and Singh, K. (2015). Fine mapping of powdery mildew resistance genes PmTb7A.1 and PmTb7A.2 in Triticum boeoticum (Boiss.) using the shotgun sequence assembly of chromosome 7AL. Theor. Appl. Genet., DOI 10.1007/s00122-015-2570-5.

Elkot, A.F.A., Chhuneja, P., Kaur, S., Saluja, M., Keller, B., Singh, K. (2015). Marker Assisted Transfer of Two Powdery Mildew Resistance Genes PmTb7A.1 and PmTb7A.2 from Triticum boeoticum (Boiss.) to Triticum aestivum (L.). PLoS ONE, 10(6): e0128297. doi:10.1371/journal.pone.0128297.

Flor, H.H.(1956). The complementary gene system in flax and flax rust. Adv. Genet., 8:29-54
Gadore, W.Y. and Patwardhan, P.G. (1965). Occurence of Erysiphe graminis var. Tritici in Bombay (Maharashtra). Curr. Sci., 34: 89.

Gerechhter-Amita, Z.K. and Vansilfhout, C.H. (1984). Resistance to powdery mildew in wild emmer (Triticum dicocciodes KORN.). Euphytica, 33(2): 273- 280.

Gupta, V., Kumar, S., Mishra, C.N., Selvakumar, R., Tiwari, V. and Sharma, I. (2014). Evaluation of wheat germplasm for powdery mildew and stripe rust resistance. In: Proceedings of National symposium on Crop Improvement for Inclusive Sustainable Development at Punjab Agricultural University Ludhiana from 7-9 Nov. 2014. PP 905-907.

Huang, X.Q. and Roder, M.(2004). Molecular mapping of powdery mildew resistance genes in wheat: A review. Euphytica, 137:203-223

Kaur, S., Saini, J., Sharma, A., Singh, K. and Chhuneja, P. (2012). Identification of variability in Blumeria graminis f.sp. tritici through molecular marker analysis. Crop Improv., 39(1): 74-79.

Leath, S. and Heun, M. (1990).Identification of powdery mildew resistance genes in cultivars of soft red winter wheat. Plant Dis., 74:747-752.

Mwale, V.M., Chilembwe, E.H.C. and Uluko, H.C. (2014). Wheat powdery mildew (Blumeria graminis f. sp. tritici):Damage effects and genetic resistance developed in wheat (Triticum aestivum) Int Res J Pl Sci., 5(1):1-16.

Patil, D.K., Hegde, R.K. and Govinda, H.G. (1969). New record of powdery mildew of wheat in Mysore state. Mysore J Agric. Sci., 3: 238-239.

Priestley, R.H. and Bayles, R.A.(1998). The contribution and value of resistant cultivars to disease control in cereals. In: Cliford B.C., Lester E. (eds): Control of Plant Diseases: Costs and Benefits. Blackwell Sci. Publ., Oxford: 53-65.

Rani, U., Munshi, G.D., Sharma, I. and Chand, K. (2008). Opportune period for screening wheat germplasm against powdery mildew in Punjab. Ind. Phytopathol., 51(1): 75-79.

Shahzad, A., Muhammad, F, Anjum, M. and Atiq-urRehman, R.(2014).Screening of wheat commercial varieties for resistance against powdery mildew (Blumeria graminis f. sp. tritici) at Kaghan valley, Pakistan. Pak. J. Phytopathol., 26 (1):7-13.

Singh, D.P., Sharma, A.K., Singh, D., Rana, S.K., Singh, K.P., Srivastava, K., Prashar, M., Bhardwaj, S.C., Pant, S.K., Brahma, R.N., Singh, K.P., Prasad, A. and Dodan, D.S. (2009) Resistance to powdery mildew in Indian wheat. Pl Dis. Res., 24: 942. 